\title{
TEMPOS DE PANDEMIA, PRÁTICAS COTIDIANAS E PROJETO DE NAÇÃO: DE QUE EVANGÉLICOS ESTAMOS FALANDO?
}

\section{Livia Reis ${ }^{2}$}

\begin{abstract}
Resumo: Neste artigo, parto de duas controvérsias públicas envolvendo os "evangélicos" e Bolsonaro no início da pandemia do Covid-19 para pensar a heterogeneidade deste segmento religioso e as disputas em torno da representaçăo do Brasil como uma nação cristá. Demonstro, também, como atos religiosos ordinários - como jejuns, oraçôes, doaçôes e açốes de assistência social - tiveram sua dimensão política evidenciada, questionada e disputada por diferentes atores em tempos extraordinários. Sugiro, ainda, que a ruptura provocada pelo novo coronavírus aponta para a urgência de se considerar as diferentes formas de se viver a religião para além das grandes igrejas, incluindo aquelas digitalmente mediadas. Por fim, argumento que a observação das práticas cotidianas dos fiéis é fundamental para complexificar as análises sobre crentes e acompanhar as transformaçóes em curso no campo religioso brasileiro.
\end{abstract}

Palavras-chave: evangélicos; pandemia; projeto de nação; religião vivida.

PANDEMIC TIMES, EVERYDAY PRACTICES AND NATION PROJECT: WHAT EVANGELICALS ARE WE TALKING ABOUT?

\begin{abstract}
In this article, I start from two public controversies involving the "evangelicals" and Bolsonaro during the Covid-19 pandemic to think about the heterogeneity of this religious segment and the disputes over the representation of Brazil as a Christian nation. I also demonstrate how ordinary religious acts, such as fasts, prayers, donations and social assistance had their political dimension highlighted, questioned and disputed by different actors in extraordinary times. I also suggest

1 Como citar: REIS, Lívia. Tempos de pandemia, práticas cotidianas e projeto de nação: de que evangélicos estamos falando? Debates do NER, Porto Alegre, ano 21, n. 40, p. 391-414, 2021.

2 Doutora em Ciências Sociais e realiza Estágio Pós-Doutoral (PNPD/CAPES) no Programa de Pós-Graduação em Antropologia Social do Museu Nacional, Universidade Federal do Rio de Janeiro, Brasil. E-mail: liviareisa@gmail.com. ORCID: https:// orcid.org/0000-0003-3696-762X.
\end{abstract}


that the rupture caused by the new coronavirus has revealed the urgency to consider the different ways of living the religion beyond the big churches, including those digitally mediated. Finally, I argue that the observation of the daily practices of the faithful is fundamental to complex analyzes on believers and to accompany the transformations underway in the Brazilian religious field.

Keywords: evangelicals; pandemic; nation project; lived religion.

\section{INTRODUÇÃO}

O recrudescimento da pandemia do Covid-19 no Brasil, em meados de março de 2020, marcou também o início de mais uma controvérsia pública envolvendo os evangélicos ${ }^{3}$ e Bolsonaro. A pauta de discussão era o fechamento das igrejas, medida sanitária adotada pela maioria dos governos estaduais e que encontrou resistência entre lideranças de diferentes denominações religiosas e alguns fiéis. Em suas redes sociais, Silas Malafaia, da Assembleia de Deus Vitória em Cristo (ADVEC), foi o maior crítico das medidas de isolamento, alertando sobre suas incontornáveis consequências econômicas. Já Edir Macedo, da Igreja Universal do Reino de Deus (IURD), também contestou o fechamento das igrejas, além de sugerir em suas prédicas on-line que os impactos emocionais e econômicos do "medo do vírus" poderiam ser maiores que o vírus em si, aconselhando que seus fiéis confiassem nos propósitos divinos. Em vídeo posteriormente excluído das

3 Usarei neste texto a categoria "evangélico" para designar cristãos não-católicos seguidores de uma religiosidade cuja origem remonta à Reforma (Mafra, 2001, p. 7), sem, entretanto, perder de vista a heterogeneidade do segmento que será apontada no decorrer do texto. A categoria "crente" também é utilizada aqui para designar este mesmo conjunto de pessoas. O termo vem sendo mobilizado por fiéis para se referir a si mesmos, atribuindo um sentido positivo a uma palavra que comumente é mobilizada de maneira pejorativa, seguindo um movimento semelhante às disputas em torno de categorias como "macumbeiro" ou "favelado". A classificação de Freston (1994) sobre o segmento evangélico será acionada para diferenciá-los entre si quando necessário.

Debates do NER, Porto Alegre, Ano 2 I, N. 40, P. 39I-4I 4, Ago./Dez. 202 I 
redes sociais, Macedo chegou a afirmar que essa era uma "tática de satanás" para causar medo e pavor nas pessoas ${ }^{4}$.

A reivindicação das lideranças, por sua vez, encontrou respaldo nas declaraçôes do próprio Presidente da República. Desde o início da pandemia, declarada pela Organização Mundial da Saúde (OMS) em 13 de março de 2020, Bolsonaro minimizou a gravidade do novo coronavírus. No dia 24 de março, em pronunciamento oficial, chamou o vírus de "gripezinha" como justificativa para que as medidas de isolamento social adotadas pelos estados fossem apenas "verticais", isto é, direcionadas aos grupos de risco, na contramão das recomendações da OMS. Seu argumento se baseava na polarização entre isolamento social e crise econômica e concluía que apenas a manutenção das atividades econômicas e das relaçôes de trabalho evitaria um "mal maior que o vírus”, o mesmo de alguns pastores evangélicos. Não por acaso, Guerreiro e Almeida (2021) partiram de algumas das controvérsias também abordadas neste artigo para discutir o que chamaram de "negacionismo pandêmico", seu projeto político e a forma comum como ele foi mobilizado por lideranças religiosas e pelo presidente Bolsonaro. $\mathrm{O}$ presente texto, por sua vez, procura agregar a essa discussão a dimensão cotidiana da religiosidade crente e apresentar a forma como outras lideranças e fiéis atravessaram a pandemia para, ao final, questionar: de que evangélicos estamos falando?

É indiscutível a importância do segmento evangélico para a eleição de Jair Bolsonaro à Presidência da República em 2018 (Alves, 2018; Almeida, 2019). Ainda que, em números absolutos, os católicos tenham sido a maioria a depositar seu voto em Bolsonaro, evangélicos ganharam em números percentuais, alcançando $69 \%$ dos votos válidos no segundo turno ${ }^{6}$. Declaradamente católico, o Presidente é casado com Michelle Bolsonaro, evangélica, e sempre acompanhou a esposa nos cultos de sua igreja, além de dominar

4 Disponível em: https:/www1.folha.uol.com.br/colunas/monicabergamo/2020/03/ video-mostra-edir-macedo-dizendo-que-coronavirus-e-inofensivo-e-que-satanas-e-midia-promovem-medo.shtml. Acesso em: 10 ago. 2020.

5 Disponível em: https://cutt.ly/jd2ylUO. Acesso em: 10 ago. 2020.

6 Divulgada em 25 de outubro. Disponível em: https://cutt.ly/cd2pTor. Acesso em: 12 ago. 2020.

Debates do NER, Porto Alegre, ANo 2I, N. 4O, P. 39I-4I 4, Ago./DeZ. 202 I 
os códigos e a gramática dos crentes. Politicamente, como explica Vital da Cunha (2020), Bolsonaro pratica um jogo de ocultação e revelação de suas bases religiosas cuja finalidade é atingir um público mais extenso, importante sobretudo em eleiçôes majoritárias, enquadrando-se no que ela chama de Aliados dos Evangélicos (ADE).

A construção dessa relação, com direito a ampla mobilização dos símbolos judaico-cristãos presentes na estética e na liturgia de sua base de apoio, não data de tempos recentes ${ }^{7}$. Em 2016, após a votação do impeachment da então presidenta Dilma Rousseff, quando sua candidatura à presidência já era dada como certa, batizou-se nas águas do Rio Jordão ${ }^{8}$, na Terra Santa, pelas mãos do pastor Everaldo, presidente do PSC, partido de Bolsonaro à época ${ }^{9}$. Desde então, vem afinando as alianças com líderes religiosos e políticos cristãos, e, durante a campanha eleitoral, conseguiu reunir a seu favor evangélicos, católicos e judeus. Confirmada a vitória, o segmento evangélico tornou-se sua maior base de apoio político, institucional e popular.

Nada disso é novidade, sabemos, mas a ruptura provocada pelo advento da pandemia evidenciou algumas disputas na já complexa presença pública da religião (Birman, 2003; Giumbelli, 2002; Montero, 2018), além de revelar as novas (e velhas) estratégias de produção da representação do Brasil como uma nação cristã, isto é, uma comunidade moral pautada por valores cristãos (Sant’Anna, 2017; Machado, 2018). Como pano de fundo, temos as tensôes

7 Vale lembrar que o recurso ao Israel mítico e às referências do Antigo Testamento é comum em igrejas pentecostais e neopentecostais (Gomes, 2011; Mafra, 2011 etc.). Afirma a autenticidade de um cristianismo que não passa pela Europa, mas liga diretamente o Brasil à Terra Santa. Mais recentemente, a bandeira de Israel vem sendo usada nas manifestaçóes de apoio a Bolsonaro e pelo próprio presidente em eventos oficiais. Para além das referências militar e de masculinidade que compóem o imaginário de proteção e cuidado próprio das bases bolsonaristas, arrisco dizer que a apropriação deste símbolo é parte da estratégias de construção de uma unidade cristá mais ampla, que, ao mesmo tempo, reforçava o alinhamento brasileiro, àquela altura, com os Estados Unidos e com Donald Trump.

8 Local onde, segundo a bíblia, Jesus foi batizado por João Batista. Pastor Everaldo foi preso por desvio de verbas da saúde durante a pandemia em agosto de 2020.

9 Disponível em: https://cutt.ly/cd2dUE8. Acesso em: 12 ago. 2020. 
provocadas pela perda da hegemonia católica como base de uma matriz cultural nacional (Steil, 1997; Sanchis, 1994), e, consequentemente, as disputas em torno de noçóes como direitos, identidade nacional e cultura.

Portanto, mais do que um conjunto disperso de eventos protagonizados por lideranças religiosas nos primeiros meses da pandemia, os dados trazidos neste texto se aproximam mais de uma abordagem caleidoscópica, embora limitada pelos efeitos da própria pandemia que me impediram de encontrar fiéis e conversar mais detidamente sobre os impactos reais do coronavírus em suas vidas cotidianas. Ainda assim, trata-se de um esforço analítico de olhar atentamente para as diferentes dimensóes e escalas desses eventos que, como bem nos ensina Menezes (2009), deve considerar suas especificidades e seus múltiplos atores.

Para isso, tomei como ponto de partida duas controvérsias que emergiram no debate público nacional: o fechamento das igrejas e o chamado ao jejum nacional convocado pela primeira vez por Bolsonaro em 2020. Durante os primeiros cinco meses da pandemia, entre março e agosto do mesmo ano, reuni diversos conteúdos jornalísticos publicados na mídia sobre os temas, participei de cultos e atividades online realizados pela IURD, pela ADVEC e pela Igreja Batista da Lagoinha, além de acompanhar sistematicamente as mídias sociais de diferentes lideranças e artistas do segmento evangélico que conheci por intermédio de interlocutores de pesquisas anteriores. Durante as atividades on-line, também pude observar as reaçóes da audiência às diferentes atividades ali propostas, e, embora não tenha sido metodologicamente possível transformar essas reaçóes em dados de pesquisa, elas me ajudaram a elaborar as questóes que apresento ao longo deste texto.

Com base nesse conjunto de dados, analisei como diferentes atores religiosos se comportaram diante das duas controvérsias públicas apresentadas acima numa tentativa de complexificar o debate sobre a heterogeneidade do segmento evangélico. Chamo atenção, ainda, para a urgência de se considerar as práticas cotidianas dos fiéis para entender as transformaçóes do campo religioso brasileiro. É sobre os desdobramentos desses acontecimentos de que trata este texto. 


\section{DESMISTIFICANDO A CONTROVÉRSIA}

Antes de continuar, entretanto, é preciso retomar a controvérsia em torno do fechamento das igrejas durante a pandemia, um imbróglio que envolveu pastores, deputados, o Poder Judiciário, a mídia, ministros do próprio governo, cientistas sociais, opinião pública e o Presidente da República. Apesar da pressáo contrária, em 26 de março Bolsonaro incluiu as "atividades religiosas de qualquer natureza" na lista de atividades essenciais autorizadas a funcionar durante a situação de emergência no país em decorrência do novo coronavírus por meio de decreto ${ }^{10}$, ainda que com orientação de que as recomendaçôes da OMS fossem seguidas.

No entanto, o avanço da crise já tinha levado muitas igrejas evangélicas, das protestantes históricas às neopentecostais, além da Igreja Católica, a adotar a transmissão online de celebraçóes por mídias sociais como Instagram, YouTube e Facebook. Em um momento no qual ainda não se tinha dimensão exata de quanto tempo duraria a pandemia, a reivindicação pela abertura das igrejas por parte de algumas lideranças visava principalmente a manutenção dos atendimentos individuais e assistenciais sob o argumento de que igrejas seriam "casas de socorro espiritual", sobretudo em tempos de incertezas. E de fato são.

Ao mesmo tempo, é importante enfatizar que o posicionamento contrário ao fechamento das igrejas não foi exclusividade de grandes lideranças midiáticas pentecostais e neopentecostais. Lideranças de igrejas congregacionais como Batistas e Metodistas, por exemplo, divergiram quanto à necessidade de fechamento total dos templos ${ }^{11}$. Isso não significa, é claro, que não tenha havido uma grande mobilização por parte de lideranças dessas mesmas igrejas para incentivar o isolamento e alertar sobre os perigos da Covid-19.

Algumas das lideranças das milhares de igrejas pentecostais autônomas espalhadas nas favelas e periferias do país nem mesmo chegaram a fechar suas

${ }^{10}$ Decreto n. ${ }^{\circ} 10.292 / 2020$.

11 Para informações sobre o racha entre lideranças evangélicas. Ver: https://www.bbc.com/ portuguese/brasil-52313890. Acesso em: 13 set. 2021. 
portas ou deixaram de atender a população que procurou por esses espaços em busca de ajuda. Outras, como no caso da profetisa Maria, apresentada por Gonçalves (2020), não hesitaram em se adaptar à nova realidade e manter o afastamento das igrejas por entenderem a importância das decisóes humanas para a vida na Terra.

Houve, ainda, lideranças que apoiaram abertamente as medidas de isolamento social, sem, no entanto, confrontar publicamente o presidente como no caso da Igreja Batista da Lagoinha. Pelo contrário, a família Valadão, que comanda a igreja, nunca deixou de mobilizar os elementos estéticos e discursivos que indicavam uma adesão aos signos do bolsonarismo, como a alusão recorrente à ideia de nação. Deputados da Bancada Evangélica, por sua vez, que apoiaram em sua maioria a abertura das igrejas e pressionaram o presidente nesse sentido, defenderam a reabertura das igrejas sob o argumento de que estariam defendendo o direito dos fiéis à liberdade religiosa.

No entanto, e é para isso que gostaria de chamar atenção, igrejas evangélicas oferecem um conjunto de atividades que vão muito além dos cultos e se estendem para além dos templos. Ofertam trabalhos assistenciais diversos para mulheres vítimas de violência doméstica, idosos, dependentes químicos, população em situação de rua, presos e egressos do sistema prisional, sem contar os cursos profissionalizantes e os próprios atendimentos individuais para resolução de problemas mais imediatos.

Como afirmei em outro texto (Menezes e Reis, 2020), trata-se de diferentes tipos e formas de assistência direcionadas a diferentes grupos sociais. Todo esse leque de atividades, por sua vez, constitutivo das práticas cotidianas dos fiéis, é tão importante para quem recebe quanto para quem doa - não apenas dinheiro, mas seu corpo, seus dons e seu tempo para a obra de Deus. O trabalho de Eva Scheliga (2010) sobre práticas de assistência social evangélicas a partir da comparação entre a IURD e a Rede Evangélica Nacional de Assistência Social (RENAS) é fundamental para entendermos a centralidade dessas atividades na religiosidade praticada por fiéis. Não por acaso, as atividades de assistência social se tornaram em meio à pandemia quase que a única forma possível aos crentes de praticarem sua 
fé - ou de "transformar a fé em obras", como costumam dizer os fiéis da IURD, já que uma "fé sem obras é uma fé morta”. Também é a forma que encontraram de intervir ativamente no mundo em que vivem - algo nada trivial, sobretudo em tempos extraordinários - e de levar a igreja para a rua, extrapolando o espaço do templo.

No caso de atividades de assistência da IURD que observei, o uso de máscara era incentivado. As fotografias divulgadas nas mídias sociais da igreja no período costumavam mostrar fiéis voluntários utilizando máscaras e obedecendo a algum distanciamento social. Imprescindivelmente, também vestiam camisas ou coletes que faziam referência à IURD e ao projeto denominacional específico do qual a ação fazia parte ${ }^{12}$ (Unisocial, Força Jovem Universal etc), de modo a demonstrar publicamente que, apesar dos templos fechados, igreja e fiéis continuavam contribuindo para a realização da obra de Deus.

Paralelamente, é importante destacar que nenhuma das grandes igrejas reivindicou publicamente a promoçáo de políticas públicas que minimizassem os impactos da pandemia, posicionamento coerente com a própria religiosidade que professam. Apesar das exceçóes, igrejas pentecostais e neopentecostais têm o empreendedorismo e a assistência como valores, de modo que as pessoas, com intermédio do Espírito Santo e da estrutura institucional, se tornam responsáveis por alcançar a prosperidade em seu sentido amplo, o que inclui criar seus próprios meios de subsistência (Lima, 2007; Mesquita, 2007), doar tempo em atividades de assistência (Scheliga, 2010) e a busca pelo bem-estar familiar (Teixeira, 2016).

Ressalta-se, ainda, que muitas das críticas à abertura das igrejas vieram acompanhadas de leituras simplistas sobre o dízimo, tantas vezes utilizado como categoria de acusação contra crentes (Mariz, 1995). Muitos dos argumentos acusavam as igrejas de não estarem dispostas a abrir mão do dízimo, o que justificaria sua contrariedade ao isolamento. Não penso

${ }^{12}$ Para um exemplo de atividade da IURD durante a pandemia. Ver: https://www.correiodopovo. com.br/not\%C3\%ADcias/geral/trabalho-social-ganha-ainda-mais-import\%C3\%A2ncia-durante-per\%C3\%ADodo-de-pandemia-1.421601. Acesso em: 13 set. 2021.

Debates do NER, Porto Alegre, ANo 2I, N. 40, P. 39I-4I 4, Ago./Dez. 202 I 
que se trate apenas disso, ainda que os impactos financeiros tenham sido relevantes. De fato, igrejas existem porque recebem doaçôes de seus fiéis, mas, se igrejas menores as utilizam para manutenção de suas atividades, as grandes denominações têm outros meios para tal, como canais de televisão, editoras, gravadoras, empresas etc. Além do mais, estudos antropológicos nos mostram que os crentes engajados, não aqueles eventuais, reconhecem e valorizam a importância fundamental das contribuiçôes em dinheiro para a continuidade dos projetos sociais e missionários promovidos permanentemente por suas igrejas (Reis, 2018; 2019) e puderam realizá-las remotamente durante a pandemia. Desse modo, ao crente torna-se possível fortalecer seu vínculo com a denominação a qual pertence e garantir a continuidade da relação com o Deus no qual confia.

Por isso, o apelo pela abertura dos templos me parece menos ligado aos interesses financeiros, que de fato existem, do que à manutenção desse laço comunitário e moral que gera pertencimento e é fundamental para o projeto de unidade cristá disputado publicamente por lideranças como Macedo, Malafaia e Bolsonaro.

\section{O CHAMADO AO JEJUM}

Quando o debate religioso parecia temporariamente resolvido pelo decreto acima mencionado, com as grandes igrejas funcionando parcialmente, Bolsonaro fez um novo movimento no início de abril de 2020 e convocou um "Ato de jejum e oração pela nação" para o enfrentamento da pandemia no dia 5/4 daquele ano. $\mathrm{O}$ vídeo de divulgação nas redes sociais, que teve como mote um versículo bíblico do Antigo Testamento ${ }^{13}$, convocava "aqueles que têm fé e acreditam", o "exército de Cristo", a se unir na "maior campanha de jejum e oração já vista na história do Brasil”, reunindo lideranças das

132 Crônicas 20:3: "Josafá decidiu consultar o Senhor e proclamou um jejum em todo reino de Judá. E Deus os respondeu: não temais, nem vos assusteis por causa desta grande multidão, pois a peleja não é vossa, mas de Deus".

Debates do NER, Porto Alegre, ANo 2I, N. 40, P. 39I-4I4, Ago./Dez. 202 I 
principais igrejas evangélicas do país. No vídeo ${ }^{14}$, não estavam representados católicos, religiôes afro-brasileiras, espíritas, judeus ou evangélicos de setores progressistas. Dos protestantes históricos, estavam a Igreja Presbiteriana do Brasil e igrejas batistas, incluindo a Batista da Lagoinha ${ }^{15}$. Lideranças como Marcio Valadão, da Batista da Lagoinha; Edir Macedo, da IURD; Silas Malafaia, da ADVEC; Hernandes, da Renascer em Cristo; Abner Ferreira, da Assembleia de Deus Madureira; Robson Rodovalho, da Sara Nossa Terra, Valdemiro Santiago, da Mundial do Poder de Deus e Teofilo Hayashi, do movimento Dunamis, apoiaram a campanha. Iris Abravanel, esposa do dono da rede de televisão SBT Silvio Santos, representou a parte judaica do apoio. Apesar da falta de pluralidade religiosa, o convite à participação na campanha era direcionado a todos os cristãos, não apenas aos evangélicos, um ponto que considero fundamental.

Para os cristãos, o dia 5/4, Domingo de Ramos, marcou o início da Semana Santa e a chegada de Jesus à Jerusalém após quarenta dias de jejum e oraçáo no deserto. Neste dia, Cristo saiu de sua quarentena para se dirigir à morte, aceitando e obedecendo a vontade de Deus. Servindo de exemplo vivo aos demais cristãos, o filho confiou nos desígnios do pai e cumpriu a promessa divina, mesmo que isso significasse injustiça, humilhação, violência e morte. Depois de alguns dias, o Cordeiro seria imolado e a palavra escrita se cumpriria na Páscoa.

Neste mesmo dia, depois de realizar um jejum até o meio-dia, Bolsonaro se reuniu no fim da tarde com diversos religiosos nos jardins do Palácio da Alvorada, sua residência oficial, para um ato transmitido ao vivo pelo Twitter, principal canal de comunicaçáo da presidência. Após conversas e sessóes de fotos - realizadas sem medidas de proteção, diga-se de passagem -, Bolsonaro se ajoelhou e participou da oração conduzida por um pastor, embora um padre católico também estivesse presente na

${ }^{14}$ Matéria sobre o Jejum publicada pela Agência Pública. Disponível em: https://apublica. org/2020/04/o-lobby-dos-evangelicos-contra-o-fechamento-das-igrejas/. Acesso em: 13 set. 2021.

${ }^{15}$ Um encontro televisivo promovido em comemoração à Páscoa foi transmitido pela TV Brasil no domingo seguinte ao Jejum e contou com a presença de católicos, judeus e evangélicos.

Debates do NER, Porto Alegre, ANo 2I, N. 40, P. 39I-4I 4, Ago./Dez. 202 I 
cerimônia. Nela, o líder religioso determinou que não haveria mais mortes causadas por coronavírus no Brasil, afirmou que Bolsonaro havia sido escolhido e ungido por Deus para conduzir este momento da nação e que ele estava ali porque o povo brasileiro assim o quis. Encerrou a solenidade afirmando que "Jesus Cristo é o Senhor do Brasil” e que, "embora o Estado seja laico", os brasileiros eram "terrivelmente cristãos", parafraseando a Ministra da Família e dos Direitos Humanos Damares Alves ${ }^{16}$.

A reproduçáo, naquele contexto, de uma frase que é táo polêmica quanto verdadeira, não foi casual. Ela sinalizava que a produção dessa unidade cristã seria mediada por valores cristâos, sobretudo aqueles presentes na chamada Retórica da Perda, "uma tática discursiva que propóe o retorno da ordem, da previsibilidade, da segurança e da unidade" (Vital da Cunha, 2020, p. 7), que, em tese, foram destruídas por governos anteriores, mais precisamente pelo Partido dos Trabalhadores (PT).

Se, como afirma Sant'Anna (2017), a "luta pela inclusão na narrativa nacional" exigiu que os crentes, num dado momento, reivindicassem a existência de um "povo evangélico" para legitimação de suas pautas, torna-se cada vez mais evidente o movimento de ampliação dessa unidade para todos os cristãos, "aqueles que crêem", como sugeria o vídeo de chamamento ao jejum. A produção dessa unidade imaginada, a nação cristã, vem sendo mobilizada por Bolsonaro e seus aliados como justificativa para a implementaçáo de uma agenda restritiva de direitos e de cerceamento de valores democráticos. Nessa narrativa, a existência de uma maioria cristá justificaria a prioridade do governo em promover a proteção da família, entendida restritivamente em sua versão heteronormativa, e dos "valores cristáos", mobilizados de forma genérica. Tão católico quanto evangélico, Jair Messias Bolsonaro emerge como o símbolo perfeito dessa articulação.

${ }^{16}$ Frase enunciada no dia de sua posse como Ministra. Disponível em: https://cutt.ly/ mff77DH. Acesso em: 26 ago. 2020. Bolsonaro também repetiu a expressão "terrivelmente cristão" ao se referir à escolha de um membro do Supremo Tribunal Federal, um compromisso que, segundo ele próprio, teria com a Bancada Evangélica e com lideranças religiosas que apoiaram sua eleição.

Debates do NER, Porto Alegre, ANo 2 I , N. 4O, P. 39I-4I 4, Ago./DeZ. 202 I 
A convocação presidencial para um jejum nacional, portanto, foi estratégica na medida em que propôs uma relação de contiguidade metonímica com as escolhas de Jesus Cristo em plena Semana Santa. O chamado ao recolhimento, à meditação e à oração, fundamentado na bíblia, reconhecendo os limites do ser humano e a onipotência divina, incentivava um sentimento de confiança em Deus e, por que não, naqueles escolhidos por Ele para dirigir a nação. Também sugeria a necessidade de sacrifício, como o de Jesus, para que Deus se compadecesse de seu povo. Em suma, visava produzir uma unidade ao mesmo tempo em que revelava a ambivalência de atos religiosos ordinários, como jejuns e oraçôes, ao evidenciar sua dimensão política (Menezes e Reis, 2020).

\section{JEJUM, UM CÓDIGO COMPARTILHADO}

A relação das religiôes com a comida tem uma longa história e diferentes contextos de mobilização. Trata-se de um campo amplo de pesquisa (Farquhar, 2006; Illman e Dalla, 2015) e a recusa à alimentação um de seus temas mais instigantes. A abstenção de certos alimentos ou mesmo a suspensão de alimentação regular por determinados períodos, seja voluntária ou por proibição, é uma prática recorrente, com diferentes significados e formas, muito comum na tradição judaico-cristã, mas também no budismo, no hinduísmo e no islamismo, sendo normalmente percebida como uma forma de desenvolvimento espiritual. Embora com outros sentidos, adeptos de religiōes afro-brasileiras também sofrem restriçóes alimentares permanentes ou ocasionais.

Ainda que possa ser mobilizado como uma forma de contestação e resistência, como nos casos de greve de fome, nos grupos cristãos que tenho pesquisado o jejum costuma ser concebido como um ato de sacrifício e clamor a Deus. Por isso, cristãos jejuam com frequência, o que não significa que sejam incentivados a passar longos períodos sem comer, mas ao ato simbólico de abrir mão de uma refeição ou alimento para que o crente demonstre a Deus que se reconhece como um ser inferior e digno de sua misericórdia. 
Entre os estudiosos do sacrifício, tema clássico da Antropologia, é ponto de convergência sua natureza contratual (Mauss, Hubert, 2005; Pina-Cabral, 1997), isto é, de troca, e o jejum proposto por Bolsonaro pode ser lido a partir dessa chave: o sacrifício individual em prol do bem comum. Para muitos evangélicos, a exemplo dos membros da IURD, o sacrifício nada tem a ver com sofrimento, mas é percebido positivamente como uma oportunidade de crescimento na fé e demonstração de sinceridade com Deus (Reis, 2018). Como um sacrifício, é parte importante da batalha espiritual que tem como finalidade última derrotar os demônios e todos os malefícios por eles causados no mundo físico. Fiéis da IURD com quem conversei em pesquisas anteriores me relataram com alegria a prática do jejum por considerar que ele possibilita o estreitamento de uma relação de intimidade com Deus. Ao mesmo tempo, também escutei lideranças iurdianas interpretando o jejum como um ato de humilhação que visa reconhecer a grandiosidade divina perante os seres humanos, reforçando a imagem de um Deus rancoroso e vingativo próprio do Antigo Testamento.

De todo modo, em geral, o jejum é percebido como um ato de renúncia e demonstração de respeito a Deus mobilizado pelos fiéis, na maior parte das vezes, para solucionar questóes pessoais. Em tempos pandêmicos, vimos as diferentes lideranças religiosas fazerem um chamado coletivo para que o objetivo último desse importante ritual fosse deslocado do plano individual e estendido à nação. Mobilizaram uma linguagem que é tão difundida quanto amplamente compreendida. Em suma, uma prática que atravessa religiôes, uma experiência que se dá no corpo, afeta os sentidos e produz sensaçóes que podem ser compartilhadas.

No dia do Jejum Nacional, acompanhei atividades religiosas em diferentes mídias sociais e observei que muitas manifestaçôes de apoio ao jejum se misturaram com a defesa de Jair Bolsonaro e/ou a oraçóes pelo futuro do Brasil. Por exemplo, Bolsonaro foi apresentado como um homem que defende valores cristãos, além de chefe da nação, pelo Pr. Marcio Valadão, da Batista da Lagoinha, que fez um culto on-line integralmente dedicado ao jejum. 
Como não poderia deixar de ser, a campanha provocou divergências, mesmo que nuançadas dentro do mundo cristão. Para além das críticas mais gerais à convocação de um jejum por um Presidente que ainda não havia sancionado o projeto de lei que instituía a renda emergencial já aprovada pelo Congresso, fiéis e lideranças também se dividiram. Alguns católicos argumentaram que não se fazia jejum aos domingos, mas às sextas, dia da paixão de Cristo, disputando a narrativa cristã ali proposta. Eyshila e Ana Paula Valadão, grandes nomes do mercado gospel, aderiram ao jejum e às oraçóes, embora incentivando o isolamento social. A própria Ana Paula Valadão e seu marido, Gustavo Bessa, do Ministério Diante do Trono, fizeram uma live na qual abordaram historicamente a temática dos jejuns em momentos de guerras e fome, citando aquele convocado pelo presidente estadunidense Abraham Lincoln durante a Guerra de Secessão nos Estados Unidos. Marco Feliciano também citou o jejum do ex-presidente estadunidense para convocar os fiéis a se humilharem em prol do futuro da nação. Além disso, atribuiu à prática do jejum não apenas o fim da guerra nos Estados Unidos, mas o fato de o país ter se tornado uma potência mundial poucos anos depois. As cantoras Aline Barros e Gabriela Rocha apoiaram o jejum publicamente, citando em suas redes o mesmo versículo bíblico do vídeo de divulgação, além de mobilizar a referência estética verde e amarela típica do bolsonarismo.

Houve, ainda, aqueles que criticaram a própria ideia de jejum, como o cantor gospel Leonardo Gonçalves, que, além de defender o isolamento, utilizou uma passagem bíblica (Isaías 58:5-10) para argumentar que não se deve fazer jejum sem a prática de caridade. Alguns cristãos "progressistas" reivindicaram o jejum e a oração como uma prática usual, entre quatro paredes, que deve ser feita sem alarde ou necessidade de convocação política. As gravadoras gospel Sony Music Gospel e Mkmusic promoveram grandes eventos on-line durante todo o dia 5/4, nos quais cantores gospel incentivaram a adoração e o louvor sem se referirem diretamente ao jejum. Outros evitaram se posicionar sobre o tema, como no caso de Fernanda Brum, que incentivou o distanciamento social durante toda a pandemia, e do Ministério de Arte cristã Cia Jeová Nissi, que neste dia divulgou em suas mídias sociais ações de distribuição de alimentos para pessoas em situação de vulnerabilidade social. 
Com esses exemplos, quero demonstrar que, embora atravessado por controvérsias, o chamamento ao jejum produziu uma unidade. De diferentes formas, cristãos foram mobilizados pela convocação presidencial porque reconheceram suas práticas, mesmo que para questioná-las, reivindicá-las ou disputá-las. Em outras palavras, o recurso discursivo de Bolsonaro e de lideranças evangélicas unificou, mas reforçou também a diversidade do mundo cristão para além da oposição entre "conservadores" e "progressistas". Isso porque, embora tenha lidado de diferentes formas com a campanha, a maioria dos atores acima citados relaciona-se entre si e com as grandes lideranças evangélicas, o que não impediu a emergência de discordâncias, ainda que eventualmente evitando o conflito direto. Por isso, enfatizo que, embora tenham grande capacidade mobilizadora que náo pode ser minimizada, nem só das grandes igrejas se constitui o segmento evangélico e o ideal moral de cristianismo que vem sendo disputado no Brasil.

\section{DE QUE EVANGÉLICOS ESTAMOS FALANDO, AFINAL?}

A heterogeneidade do segmento evangélico é um dado e a própria categoria um objeto de disputa. De acordo com o Censo de 2010, 86,5\% da população brasileira se identifica como cristã, do qual $22 \%$ evangélica $^{17}$, e, naquela altura, $5 \%$ dos evangélicos não estava vinculado a uma denominação religiosa. Depois dos cristãos, como segundo maior segmento "religioso", está o "sem religião", totalizando $8 \%$ da população, o que não significa que sejam pessoas desprovidas de crença ou moralidades religiosas.

De 2010 pra cá, entretanto, muita coisa mudou. Devido à ampliação do acesso tecnológico e da difusão da internet, cada vez mais tem sido possível existir enquanto cristão sem pertencer a uma denominação específica. Para além da desigrejização e do múltiplo pertencimento, acompanhamos nas últimas décadas a consolidação dos grandes Ministérios ${ }^{18}$ e a proliferação

${ }^{17}$ Pesquisa do Datafolha divulgada em janeiro de 2020 mostra que $31 \%$ da população brasileira é evangélica. Disponível em: https://cutt.ly/xff5t9n. Acesso em: 27 ago. 2020.

${ }^{18}$ Cf. Machado, (2018); Rosas (2015). 
nas mídias sociais de influencers espirituais que utilizam tecnologias digitais como meio de comunicação com fiéis e de mediação com o divino. É importante destacar que essas figuras alcançam milhóes de seguidores e que uma transmissão on-line no Youtube ou no Instagram, por exemplo, chega facilmente a mais de um milhão de acessos. Populariza-setambém a existência de células - reuniôes mais íntimas para estudo da bíblia e oração -, adotadas por artistas como a atriz Bruna Marquezine, o youtuber Whindersson Nunes e a cantora Ludmilla. Também é possível encontrar formas alternativas de estudo do cristianismo, como cursos on-line ${ }^{19}$ que abordam desde temas como conservadorismo cristão a estudos de partes da Bíblia, muitas vezes ligados a Ministérios nacionais e internacionais, como o Dunamis. Além disso, a busca dos fiéis pelo êxtase religioso através da arte e do entretenimento, como novelas, teatros e filmes cristãos, também disponibilizados em plataformas de streaming, que foram particularmente impulsionadas pela pandemia ${ }^{20}$. Por fim, embora a lista não seja exaustiva, as grandes produçóes musicais direcionadas ao público jovem, como o The Send, de origem norte-americana, que neste ano reuniu 1,7 milhôes de pessoas e contou com a presença de Bolsonaro e Damares no evento de Brasília.

Por isso, antes de tecer afirmaçôes generalizantes sobre evangélicos no Brasil, é urgente considerar, em primeiro lugar, que este segmento tem um rosto que é majoritariamente pobre, negro e feminino ${ }^{21}$, o que reafirma a centralidade das políticas de assistência, escuta e cuidado oferecidas pelas igrejas. Deslegitimá-las enquanto "assistencialismo" ou questionar sua importância para autonomia das mulheres é um equívoco. Em segundo lugar, os movimentos produzidos cotidianamente pelos próprios crentes e aquilo que eles dizem sentir, viver e reivindicar são tão relevantes quanto os discursos das lideranças. Priorizar em nossas análises as narrativas institucionais significa reconhecer uma hierarquia entre as formas de viver e apreender a religião

${ }^{19}$ Como, por exemplo, o "Jesus is Cool" e o movimento Dunamis.

${ }^{20}$ Como por exemplo a Univervídeos, da IURD, e a Nissiplay, da Cia Jeová Nissi.

${ }^{21}$ Pesquisa do Datafolha. Disponível em: https://cutt.ly/xff5t9n. Acesso em: 27 ago. 2020. 
que ignora suas contradiçóes e ambivalências (Schielke e Debevec, 2012). Nesse sentido, deslocar o foco de nossas análises para a infinidade de novas formas de viver a religiosidade que têm se popularizado entre os crentes é fundamental para compreendermos os novos sentidos atribuídos à ideia de ser cristão e o que a ideia de uma nação cristã representa.

Digo isso porque engana-se quem pensa que "religiáo" diz respeito apenas à crença num ente transcendental. Às vezes sim, mas também não, pois envolve o compartilhamento de um conjunto de moralidades que incide sobre a forma como as pessoas observam e se apresentam no mundo. Como bem nos lembra Herzfeld (2014), isso que convencionamos chamar de religiáo também ajuda as pessoas a ordenar e dar sentido ao mundo em que vivem, a começar pela própria concepçáo de tempo.

Para os cristãos, por exemplo, a noção de tempo não é linear, mas marcada por rupturas intensas que exemplifico aqui de três formas. Em primeiro lugar, nosso calendário cristão. $\mathrm{O}$ nascimento de Jesus instituiu um antes e um depois, dando início à contagem do tempo que rege boa parte do planeta. Segundo, a noção de conversão. Ao se converterem, os crentes passam a dividir sua própria existência num antes e depois, incorporando não só a teologia, mas moralidades da fé que professam. Embora não sejam inquestionáveis, mas negociadas no mundo fragmentado no qual circulam, as novas leituras sobre o mundo se tornam uma espécie de bússola que os orienta. Por fim, a escatalogia. Embora diversos, os cristãos têm em comum a certeza do fim do mundo tal como o conhecemos. Cristo voltará para seu reinado milenar, como revelado na Bíblia, e um bom cristáo deve trabalhar para que outros tenham a oportunidade de salvação, por isso o proselitismo intenso.

O surgimento do novo coronavírus, por sua vez, tem sido lido como mais uma ruptura no tempo, agora para cristãos e não-cristáos. O acompanhamento on-line de atividades religiosas durante a pandemia me permitiu identificar que muitos crentes compartilhavam uma grande angústia em relação ao desconhecimento do futuro. Era um discurso presente nas ministraçôes on-line feitas por lideranças, mas também nas caixas de comentários em que os relatos se multiplicavam a cada segundo. Em muitas dessas 
atividades, fiéis se comportavam como se estivessem na igreja, interagindo entre si, escrevendo e compartilhando relatos sobre como haviam sido tomados pelo fogo do Espírito Santo, apesar de seus medos.

Se, para as pessoas em geral, o período de isolamento foi percebido como uma provação e marcado pela busca por bem-estar físico e emocional, é razoável que cristãos tenham mobilizado suas próprias técnicas em prol do bem-estar individual e coletivo. O Papa Francisco, vale lembrar, fez algo semelhante também durante a quaresma, em escala mundial, ao celebrar os rituais de Páscoa no Vaticano sem qualquer público, embora transmitido on-line, produzindo imagens que percorreram o mundo e emocionaram pessoas de diferentes religióes.

Por outro lado, essa pesquisa também revelou como algumas lideranças mobilizaram a pandemia para fomentar o pânico moral entre fiéis. No dia do jejum, o Bispo Agenor Duque, da Igreja Plenitude, convocou milhares de fiéis para as ruas de São Paulo, onde, ajoelhados, vestindo panos de saco em sinal de humilhação e envoltos por bandeiras do Brasil, oraram determinando o fim da pandemia e o renascimento do Brasil, produzindo cenas típicas de filmes sobre seitas milenaristas aguardando o fim do mundo. De maneira semelhante, áudios de WhatsApp recebidos por uma rede de crentes moradores de favelas cariocas, de autoria de pastores de igrejas autônomas, alertavam sobre um fim do mundo muito próximo, que demônios estariam soltos nas ruas e que todos deveriam permanecer em suas casas, em oração, caso quisessem se salvar.

A imagem apocalíptica, entretanto, é intencional, é política e joga com a ideia de ruptura no tempo compartilhada coletivamente. $\mathrm{O}$ sentimento público comum era de medo, seja entre crentes ou não. No caso da parcela mais pobre da população, a maioria dos evangélicos, um medo ainda mais potencializado pela desigualdade social. Assim, se a imprevisibilidade sobre o futuro faz com que o pensamento religioso seja, ordinariamente, uma importante forma de organizar o universo (Herzfeld, 2014), a ameaça extraordinária do Covid-19 fez da religiosidade, em suas diferentes formas, um instrumento fundamental que não deve ser desautorizado, mas, ao contrário, compreendido em sua complexidade. 


\section{ConsideraçóEs Finais}

Neste texto, procurei demonstrar que a pandemia vem mobilizando a fé cristã de diversas formas e, mais importante, salientando transformações nas práticas cristãs que podem servir de guia para análises futuras. $\mathrm{O}$ avivamento da rua Azusa, por exemplo, fenômeno que deu origem ao pentecostalismo nos Estados Unidos no séc. XX, ganhou força depois de uma tragédia - o terremoto na cidade de São Francisco, Califórnia -, em meio a um contexto político de segregação racial. Em sua origem, portanto, o pentecostalismo está atrelado à ideia de ruptura e teve como mote a busca pela igualdade entre negros e brancos, isto é, à produção de uma fé apostólica que unia pela universalidade, não pela diferença.

Nos últimos 40 anos, o Brasil deixou de ser um país majoritariamente católico para se tornar um país majoritariamente cristáo, mas a produção de uma unidade cristã, ainda que potencializada com a eleição de Bolsonaro, ainda está em disputa. Em comum, o fato de que muitos cristãos consideram que este mundo, tal como o conhecemos, está enfermo e precisa ser reinventado. No entanto, os sentidos dessa reinvenção são múltiplos e mobilizam diferentes atores, além de inimigos visíveis e invisíveis em diversas escalas.

Assim, se, por um lado, a produção dessa unidade fortalece vínculos institucionais distintos, incluindo aqueles mais escusos, além de aglutinar cristãos desigrejados, por outro, evidencia as fissuras do segmento evangélico e os limites das pretensóes de poder dos figuróes das megaigrejas ou do Congresso. Não por acaso, um novo chamamento ao Jejum, realizado por Bolsonaro um ano após o primeiro, em 29 de março de 2021, não promoveu a mesma comoção do que o primeiro, e nem mesmo mobilizou o mesmo número de lideranças. Por isso, mais do que se prender a críticas pejorativas sobre dinheiro ou ao uso utilitário da religião (do outro), devemos estar atentos à forma como a narrativa de mais uma ruptura vem sendo construída e percebida coletivamente, no cotidiano dos próprios crentes, mais próximo do que eles vivem como religiáo e do que compreendem como justiça social, 
direitos e cidadania. Dentro, mas, sobretudo, fora das grandes igrejas. Fora, mas cada vez mais dentro do mundo digital - herança incontornável dessa pandemia. $\mathrm{O}$ jogo ainda está em aberto e não sabemos qual cristianismo sairá fortalecido no novo mundo pós-coronavírus.

\section{REFERÊNCIAS}

ALMEIDA, Ronaldo de. Bolsonaro presidente: conservadorismo, evangélicos e a crise brasileira. Novos Estudos Cebrap, São Paulo, v. 38, p. 185-213, 2019. ALVES, José Eustáquio Diniz. O voto evangélico garantiu a eleição de Jair Bolsonaro. EcoDebate, 31 out. 2018. Disponível em: https://cutt.ly/rff6zU8. Acesso em: 27 ago. 2020.

BIRMAN, Patrícia (org). Religião e espaço público. São Paulo: Attar; CNPq; Pronex, 2003.

FARQUHAR, Judith. Food, Eating, and the Good Life. In: TILLEY, Christopher; KEANE, Webb; KUCHLER, Susanne; SPYER, Patricia e ROWLANDS, Michael Rowlands. Handbook of material culture. Sage Publications, 2006. p. 145-160.

FRESTON, Paul. Breve história do pentecostalismo brasileiro. In: ANTONIAZZI, Alberto et al. Nem anjos nem demônios: interpretaçóes sociológicas do pentecostalismo. Petrópolis: Vozes, 1994. p. 67-162.

GIUMBELLI, Emerson. O Fim da Religião: Dilemas da Liberdade Religiosa no Brasil e na França. São Paulo: Attar/PRONEX, 2002.

GOMES, Edilaine. A Era das Catedrais: a autenticidade em exibição. Rio de Janeiro: Garamond, 2011.

GONÇALVES, Reia Silvia. "O vírus é de Deus, mas o Presidente não pensa na saúde do povo":sobre sofrimento, doenças e teodicéias. In: GROSSI, Miriam; TONIOL, Rodrigo (org.). Cientistas Sociais e o Coronavírus. São Paulo: Anpocs; Florianópolis: Tribo da Ilha, 2020. p.508-512. 
GUERREIRO, Clayton; ALMEIDA, Ronaldo. Negacionismo religioso: Bolsonaro e lideranças evangélicas na pandemia do covid-19. Religião \& Sociedade, Rio de Janeiro, v. 41, n. 2, p. 49-73, 2021

HERZFELD, Michael. Antropologia: prática teórica na cultura e na sociedade. Petrópolis, RJ: Vozes, 2014.

ILLMAN, Ruth; DAHLA, Bjorn. Religion and Food. Scripta Instituti Donneriani Aboensis 26, 2015, p. 378.

LIMA, Diana. "Trabalho", "mudança de vida" e "prosperidade" entre fiéis da Igreja Universal do Reino de Deus. Religiāo \& Sociedade, Rio de Janeiro, v. 27, n. 1, 2007.

MARIZ, Cecília Loreto. Perspectivas sociológicas sobre o pentecostalismo e o neopentecostalismo. Revista de Cultura Teológica, São Paulo, n. 3, p. 37-52, 1995.

MACHADO, Carly. Evangélicos, mídias e periferias urbanas: questões para um diálogo sobre religião, cidade, nação e sociedade civil no Brasil contemporâneo. Debates do NER, Porto Alegre, ano 19, n. 33, p. 58-80, jan./jul. 2018.

MAFRA, Clara. Os evangélicos. Rio de Janeiro: Jorge Zahar Editora, 2001.

MAFRA, Clara. A "arma da cultura" e os "universalismos parciais". MANA, v. 17, n. 3, p. 607-624, 2011.

MAUSS, Marcel; HUBERT, Henri. Sobre o sacrifício. São Paulo: Cosac \& Naify, 2005.

MONTERO, Paula. Religião cívica, religião civil e religião pública: continuidades e descontinuidades. Debates do NER, Porto Alegre, ano 19, n. 33, p. 15-39, jan./jul. 2018.

MESQUITA, Wania. Correndo atrás da Prosperidade: Trabalho e Empreendedorismo entre fiéis neopentecostais. Ciencias Sociales Y Religión/Ciências Sociais E Religião, Campinas, ano 9, n. 9, p. 195-215, 2007. 
MENEZES, Renata de Castro. Revisitando Saint Besse - ou, o que Robert Hertz e a Escola Francesa de Sociologia ainda têm a nos dizer sobre festa. Religião \& Sociedade, Rio de Janeiro, v. 29, n. 1, p. 179-199, 2009.

MENEZES, Renata de Castro; REIS, Lívia. Religião e Covid: notas sobre cristianismos. In: GROSSI, Miriam; TONIOL, Rodrigo (org.). Cientistas Sociais e o Coronavírus. São Paulo: Anpocs; Florianópolis: Tribo da Ilha, 2020. p. 513-517.

PINA CABRAL, João de. O pagamento do santo: uma tipologia interpretativa dos ex-votos no contexto sócio-cultural do noroeste português. In: MUSEU ANTROPOLÓGICO. Milagre q fez. Coimbra: Museu Antropológico de Coimbra, 1997. p. 79-104.

ROSAS, Nina. Dominação evangélica no Brasil: o caso do grupo musical Diante do Trono. Contemporânea: Revista de Sociologia da UFSCAR, v. 5, p. 235-258, 2015.

REIS, Lívia. Ser Universal: crentes engajados e práticas cotidianas na cidade de Maputo. 2018. Tese (Doutorado em Ciências Sociais) - Universidade do Estado do Rio de Janeiro, Rio de Janeiro, 2018.

REIS, Lívia. Estreitando alianças, criando crentes moçambicanos: notas sobre a cooperação entre a Igreja Universal do Reino de Deus e a Frelimo na cidade de Maputo. Revista De Antropologia, São Paulo, v. 62, n. 3, p. 584-609, 2019.

SANCHIS, Pierre. O repto pentecostal à “cultura católico-brasileira”. Revista de Antropologia, São Paulo, p. 145-181, 1994.

SCHELIGA, Eva Lenita. Educando sentidos, orientando uma práxis: etnografia das práticas assistenciais de evangélicos brasileiros. São Paulo, 2010. 326 f. Tese (Doutorado em Antropologia Social) - Faculdade de Filosofia, Letras e Ciências Humanas, Universidade de São Paulo, 2010.

STEIL, Carlos (org.). Globalização e religião. Petrópolis: Vozes, 1997. 
SANTA'ANA, Raquel. A nação cujo Deus é o Senhor: a imaginação de uma coletividade evangélica a partir da Marcha para Jesus. 2017. 263 f. Tese (Doutorado em Antropologia Social) - Museu Nacional, Universidade Federal do Rio de Janeiro, Rio de Janeiro, 2017.

SCHIELKE, Samuli; DEBEVEC, Liza (org.). Ordinary lives and grand schemes: an anthropology of everyday religion, Brooklyn: Berhahn Books, 2012.

TEIXEIRA, Jacqueline Moraes. A mulher universal: corpo, gênero e pedagogia da prosperidade. Rio de Janeiro: Mar de Ideias - Navegação Cultural, 2016. VITAL DA CUNHA, Christina. Retórica da perda e os Aliados dos Evangélicos na política brasileira. In: CARRANZA, Brenda; GUADALUPE, José Luiz Perez (org.). Novo ativismo político no Brasil: os evangélicos do sec. XXI, 2020.

Recebido em: 21/05/2021

Aprovado em: 15/09/2021 
